Journal of Clinical Investigation

Vol. 41, No. 11, 1962

\title{
THE EFFECTS OF AUTONOMIC NERVOUS SYSTEM INHIBITION ON THE CIRCULATORY RESPONSE TO MUSCULAR EXERCISE *
}

\author{
By RICHARD L. KAHLER, THOMAS E. GAFFNEY, AND EUGENE BRAUNWALD
}

(From the Cardiology Branch, National Heart Institute, Bethesda, Md.)

(Submitted for publication April 24, 1962 ; accepted July 19, 1962)

One of the primary functions performed by the cardiovascular system is the delivery of oxygen and metabolic substrates to the peripheral tissues during varying levels of their activity. Accordingly, the manner in which the circulation is altered during muscular activity and the consideration that the cardiovascular response is mediated through the interaction of a number of mechanisms, prominent among which is the activity of the autonomic nervous system, are of interest. The present investigation was undertaken in an attempt to clarify the role of this mechanism in normal human subjects by determining the manner in which inhibition of the parasympathetic and the sympathetic divisions, or both, affected the circulatory response to exercise. Two pharmacologic agents were employed to produce functional inhibition of the autonomic nervous system; atropine was used to inhibit the parasympathetic division, and guanethidine, an effective adrenergic blocking agent (1), was used to interfere with the activity of the sympathetic division.

\section{METHODS}

The investigations were carried out on six healthy male subjects whose ages ranged from 18 to 20 years. All studies were performed in the supine position, and measurements of heart rate, cardiac output, arterial blood pressure, and oxygen consumption were made at rest and during exercise in the four investigations performed on each subject. The first (control study) was performed without prior drug administration. Forty-five minutes after its completion, $2 \mathrm{mg}$ of atropine sulfate was administered intravenously, and 5 minutes later the resting measurements were repeated, followed immediately by exercise. After these two studies oral guanethidine administration was begun at a daily dosage of $10 \mathrm{mg}$, which was progressively increased by $5 \mathrm{mg}$ increments every other day for a period of 21 to 26 days. The

* Presented in part at the meeting of the Eastern Section of the American Federation for Clinical Research, Philadelphia, January 11, 1962. maximum daily dosage reached ranged from 50 to $85 \mathrm{mg}$ for each subject. The subjects were questioned about the side effects of guanethidine, and supine and standing blood pressures were recorded twice daily. The third study was performed at the end of the period of guanethidine administration while subjects were receiving the maximal doses. Forty-five minutes after completion of the third study, $2 \mathrm{mg}$ of atropine sulfate was again administered intravenously, and five minutes later the fourth study was begun.

Each subject had been thoroughly familiarized with the laboratory, the equipment, and the experimental procedure prior to the study, and all observations were carried out with the subjects in the postabsorptive state. The control resting measurements were carried out approximately 20 minutes after insertion of the catheter and needles with the subject's feet placed on the pedals of a bicycle ergometer. Exercise consisted of pedaling the ergometer at a constant rate of $55 \mathrm{rpm}$ at an external work load of approximately 1,500 foot-pounds per minute for 10 minutes. Circulatory and respiratory measurements were repeated between the eighth and tenth minutes of exercise. Cardiac output was measured by the indicator dilution technic using indocyanine dye. The dye $(2.50 \mathrm{mg})$ was injected through a $50-\mathrm{cm}$ polyethylene catheter ( $\mathrm{PE}$ no. $50,0.58 \mathrm{~mm}$ ID) which had been introduced percutaneously through an antecubital vein into the superior vena cava. Blood was sampled from the opposite brachial artery through an indwelling arterial needle, and was delivered to a cuvet densitometer by means of a polyethylene catheter and a motor-driven, suction syringe. The precise details of the method employed for cardiac output measurement, including the calibration technic, have been presented elsewhere (2). The cardiac output was calculated by utilizing the formula of Stewart and Hamilton after the inscribed dilution curves had been replotted on semilogarithmic paper. The accuracy of this technic for the measurement of cardiac output had been validated previously by direct measurements in circulatory models and in studies using flowmeters for the measurement of cardiac output in dogs $(3,4)$. In another study, identical technics were used to measure cardiac output in duplicate on 20 occasions. The standard deviation of the differences between these determinations was $182 \mathrm{ml}$ per minute, or 6 per cent of the mean value of the cardiac output (5).

Brachial arterial and central venous pressures were recorded by means of Statham pressure transducers im- 
mediately before and after each dilution curve. The electrocardiogram, pressure pulses, indicator dilution curves, and the signal marking the instant of injection were recorded by using a photographic cathode ray recorder at a paper speed of $5 \mathrm{~mm}$ per second. Simultaneously with each measurement of cardiac output, the minute ventilation, oxygen consumption, and carbon dioxide production were determined by an open circuit respiratory system, and the micro-Scholander technic (6) was used for gas analysis. Left ventricular minute work in kilogrammeters per square meter BSA was calculated as the product of cardiac index (liters per minute per square meter) and mean arterial pressure (centimeters $\mathrm{H}_{2} \mathrm{O}$ ) divided by 100 . Left ventricular stroke work in grammeters per square meter BSA was calculated as the product of stroke volume index (milliliters per square meter) and mean arterial pressure (centimeters $\mathrm{H}_{2} \mathrm{O}$ ) divided by 100 .

\section{RESULTS}

\section{Control studies}

Oxygen consumption rose from an average of $147.8 \mathrm{ml}$ per minute per $\mathrm{m}^{2}$ at rest to an average of $663.6 \mathrm{ml}$ per minute per $\mathrm{m}^{2}$ during exercise. This was accompanied by elevations of cardiac index, heart rate, stroke volume index, left ventricular stroke and minute work, arteriovenous oxygen differences, and arterial pressure, which are presented in detail in Table I (see also Figure 1).

\section{Studies after atropine (Table I)}

Rest. When compared to the mean values obtained at rest in the control state, atropine administration resulted in a significant increase in the mean heart rate ( 124.0 compared to 75.2 per minute, $\mathrm{p}<.01)$, whereas a significant decline occurred in the stroke volume index (39.4 compared to $51.0 \mathrm{ml}$ per $\left.\mathrm{m}^{2}, \mathrm{p}<.05\right)$. Although the mean values for cardiac index and left ventricular minute work index were higher after atropine, these changes were not statistically significant $(\mathrm{p}<$ $.10)$.

Exercise. When compared to the mean values observed during exercise in the control state, atropine administration resulted in heart rates that were significantly more rapid ( 157.5 compared to 126.7 per minute, $\mathrm{p}<.01)$ and mean values for the stroke volume index (49.9 compared to 59.5 $\mathrm{ml}$ per $\left.\mathrm{m}^{2}, \mathrm{p}<.05\right)$ and left ventricular stroke work index (66.0 compared to $82.4 \mathrm{~g}-\mathrm{m}, \mathrm{p}<.05$ ) that were significantly lower than during the control exercise period. Values for the other measurements listed in Table I were not significantly different from the values observed during exercise performed in the control state.

TABLE I

Measurements at rest and during exercise during the control period and after atropine*

\begin{tabular}{|c|c|c|c|c|c|c|c|c|c|c|c|c|c|c|c|c|}
\hline \multirow[b]{2}{*}{ Subject } & \multirow[b]{2}{*}{ BSA } & \multicolumn{3}{|c|}{$\dot{\mathrm{V}}_{2}$} & \multicolumn{2}{|c|}{$\begin{array}{c}\text { Cardiac } \\
\text { index }\end{array}$} & \multicolumn{2}{|c|}{ Heart rate } & \multicolumn{2}{|c|}{$\begin{array}{c}\text { Stroke vol } \\
\text { index }\end{array}$} & \multicolumn{2}{|c|}{$\begin{array}{l}\text { Mean art. } \\
\text { pressure }\end{array}$} & \multicolumn{2}{|c|}{$\begin{array}{c}\text { L.V. stroke } \\
\text { work }\end{array}$} & \multicolumn{2}{|c|}{$\underset{\text { work }}{\text { L.V. minute }}$} \\
\hline & & & $\mathrm{C}$ & A & C & A & C & A & $\mathrm{C}$ & A & $\mathrm{C}$ & $\mathbf{A}$ & C & A & C & A \\
\hline A.W. & 1.86 & $\begin{array}{l}\mathbf{R} \\
\mathbf{E}\end{array}$ & $\begin{array}{l}128 \\
531\end{array}$ & $\begin{array}{l}146 \\
605\end{array}$ & $\begin{array}{l}3.40 \\
6.74\end{array}$ & $\begin{array}{l}5.40 \\
7.64\end{array}$ & $\begin{array}{r}75 \\
128\end{array}$ & $\begin{array}{l}128 \\
155\end{array}$ & $\begin{array}{l}45.4 \\
52.6\end{array}$ & $\begin{array}{l}42.3 \\
49.3\end{array}$ & $\begin{array}{r}85 \\
102\end{array}$ & $\begin{array}{l}98 \\
98\end{array}$ & $\begin{array}{l}52.5 \\
73.0\end{array}$ & $\begin{array}{l}56.4 \\
65.6\end{array}$ & $\begin{array}{l}3.94 \\
9.34\end{array}$ & $\begin{array}{r}7.22 \\
10.17\end{array}$ \\
\hline W.C. & 1.68 & $\begin{array}{l}\mathbf{R} \\
\mathbf{E}\end{array}$ & $\begin{array}{l}209 \\
811\end{array}$ & $\begin{array}{l}204 \\
747\end{array}$ & $\begin{array}{l}4.70 \\
9.38\end{array}$ & $\begin{array}{l}4.59 \\
9.50\end{array}$ & $\begin{array}{r}80 \\
130\end{array}$ & $\begin{array}{l}123 \\
173\end{array}$ & $\begin{array}{l}58.8 \\
71.2\end{array}$ & $\begin{array}{l}37.3 \\
54.9\end{array}$ & $\begin{array}{r}87 \\
106\end{array}$ & $\begin{array}{l}80 \\
91\end{array}$ & $\begin{array}{r}69.9 \\
103.9\end{array}$ & $\begin{array}{l}40.5 \\
68.0\end{array}$ & $\begin{array}{r}5.59 \\
13.50\end{array}$ & $\begin{array}{r}4.98 \\
11.76\end{array}$ \\
\hline D.S. & 1.66 & $\begin{array}{l}\mathrm{R} \\
\mathrm{E}\end{array}$ & $\begin{array}{l}126 \\
702\end{array}$ & $\begin{array}{l}127 \\
780\end{array}$ & $\begin{array}{l}3.78 \\
6.49\end{array}$ & $\begin{array}{l}5.91 \\
8.25\end{array}$ & $\begin{array}{r}72 \\
144\end{array}$ & $\begin{array}{l}135 \\
168\end{array}$ & $\begin{array}{l}52.4 \\
45.0\end{array}$ & $\begin{array}{l}43.8 \\
49.1\end{array}$ & $\begin{array}{r}87 \\
115\end{array}$ & $\begin{array}{r}92 \\
115\end{array}$ & $\begin{array}{l}61.9 \\
70.4\end{array}$ & $\begin{array}{l}54.8 \\
76.8\end{array}$ & $\begin{array}{r}4.46 \\
10.14\end{array}$ & $\begin{array}{r}7.39 \\
12.89\end{array}$ \\
\hline R.A. & 1.86 & $\stackrel{\mathbf{R}}{\mathrm{E}}$ & 626 & $\begin{array}{l}130 \\
603\end{array}$ & $\begin{array}{l}3.03 \\
8.01\end{array}$ & $\begin{array}{l}4.68 \\
7.49\end{array}$ & $\begin{array}{r}78 \\
128\end{array}$ & $\begin{array}{l}120 \\
156\end{array}$ & $\begin{array}{l}38.8 \\
62.5\end{array}$ & $\begin{array}{l}39.0 \\
48.0\end{array}$ & $\begin{array}{l}92 \\
96\end{array}$ & $\begin{array}{l}93 \\
94\end{array}$ & $\begin{array}{l}48.5 \\
81.6\end{array}$ & $\begin{array}{l}49.4 \\
61.4\end{array}$ & $\begin{array}{r}3.78 \\
10.45\end{array}$ & $\begin{array}{l}5.93 \\
9.58\end{array}$ \\
\hline R.W. & 1.75 & $\begin{array}{l}\mathbf{R} \\
\mathbf{E}\end{array}$ & $\begin{array}{l}142 \\
650\end{array}$ & $\begin{array}{l}170 \\
586\end{array}$ & $\begin{array}{l}4.41 \\
6.81\end{array}$ & $\begin{array}{l}3.99 \\
6.74\end{array}$ & $\begin{array}{r}80 \\
122\end{array}$ & $\begin{array}{l}120 \\
147\end{array}$ & $\begin{array}{l}55.1 \\
55.9\end{array}$ & $\begin{array}{l}33.3 \\
45.9\end{array}$ & $\begin{array}{r}91 \\
102\end{array}$ & $\begin{array}{r}105 \\
98\end{array}$ & $\begin{array}{l}68.3 \\
77.5\end{array}$ & $\begin{array}{l}37.4 \\
61.1\end{array}$ & $\begin{array}{l}5.46 \\
9.46\end{array}$ & $\begin{array}{l}5.67 \\
8.99\end{array}$ \\
\hline E.T. & 1.88 & $\stackrel{\mathbf{R}}{\mathrm{E}}$ & $\begin{array}{l}134 \\
662\end{array}$ & 144 & $\begin{array}{l}3.68 \\
7.66\end{array}$ & $\begin{array}{l}4.81 \\
7.58\end{array}$ & $\begin{array}{r}66 \\
108\end{array}$ & $\begin{array}{l}118 \\
146\end{array}$ & $\begin{array}{l}55.6 \\
71.0\end{array}$ & $\begin{array}{l}40.8 \\
51.9\end{array}$ & $\begin{array}{l}81 \\
91\end{array}$ & $\begin{array}{l}78 \\
89\end{array}$ & $\begin{array}{l}61.3 \\
87.9\end{array}$ & $\begin{array}{l}43.3 \\
62.8\end{array}$ & $\begin{array}{l}4.04 \\
9.49\end{array}$ & $\begin{array}{l}5.10 \\
9.16\end{array}$ \\
\hline \multicolumn{2}{|l|}{$\begin{array}{l}\text { Mean } \\
\text { Comparison }\end{array}$} & $\mathbf{R}$ & \multicolumn{2}{|c|}{$\underset{p>.10}{147.8} 153.5$} & \multicolumn{2}{|c|}{$\underset{\mathrm{p}<.10}{3.84}$} & \multicolumn{2}{|c|}{$\underset{\mathrm{p}}{75.2}<124.0$} & \multicolumn{2}{|c|}{$\begin{array}{c}51.0 \\
\mathrm{p}<.05\end{array}$} & \multicolumn{2}{|c|}{$\underset{p}{87.2} \stackrel{91.0}{0}$} & \multicolumn{2}{|c|}{$\underset{p}{60.4}<.10$} & \multicolumn{2}{|c|}{$\underset{p}{4.54}<.10^{6.04}$} \\
\hline \multicolumn{2}{|l|}{$\begin{array}{l}\text { Mean } \\
\text { Comparison }\end{array}$} & $\mathrm{E}$ & \multicolumn{2}{|c|}{${ }_{p}^{663.6}{ }^{6.10}{ }^{684.0}$} & \multicolumn{2}{|c|}{$\begin{array}{c}7.51 \\
\mathrm{p}>.10\end{array}$} & \multicolumn{2}{|c|}{$\underset{p}{126.7}<.01$} & \multicolumn{2}{|c|}{$\begin{array}{c}59.5 \\
\mathrm{p}<.05\end{array}$} & \multicolumn{2}{|c|}{$\underset{p}{102.0}<.10$} & \multicolumn{2}{|c|}{$\begin{array}{c}82.4 \\
\mathrm{p}<.05\end{array}$} & \multicolumn{2}{|c|}{${ }_{p>.10}^{10.40}$} \\
\hline \multicolumn{2}{|l|}{$\begin{array}{l}\text { Effect of } \\
\text { exercise }\end{array}$} & \multicolumn{3}{|c|}{$\mathrm{p}>.10$} & \multicolumn{2}{|c|}{$p>.10$} & \multicolumn{2}{|c|}{$p<.05$} & \multicolumn{2}{|c|}{$\mathrm{p}>.10$} & \multicolumn{2}{|c|}{$p<.05$} & \multicolumn{2}{|c|}{$\mathrm{p}>.10$} & \multicolumn{2}{|c|}{$p<.05$} \\
\hline
\end{tabular}

* BSA = body surface area in $\mathrm{m}^{2}, \mathrm{R}=$ study at rest $\mathrm{E}=$ study during exercise; $\mathrm{C}=$ control study (no drug); $\mathrm{A}=$ study after atropine. $\dot{\text { Voz }}=$ oxygen consumption in $\mathrm{ml}^{1}$ per minute per $\mathrm{m}^{2}$. Cardiac index in $\mathrm{L}$ per minute per $\mathrm{m}^{2}$; stroke volume index in ml per beat per $\mathrm{m}^{2}$; mean arterial pressure in mm Hg. L.V. =left ventricular; stroke work in gram-meters per $\mathrm{m}^{2}$; minute work in kilogram-meters per $\mathrm{m}^{2}$. Comparison refers to the statistical difference between the mean values after the drug and during the control period. Effect of exercise refers to the statistical differences between the effect of exercise before the drug and the effect of exercise after the drug. 

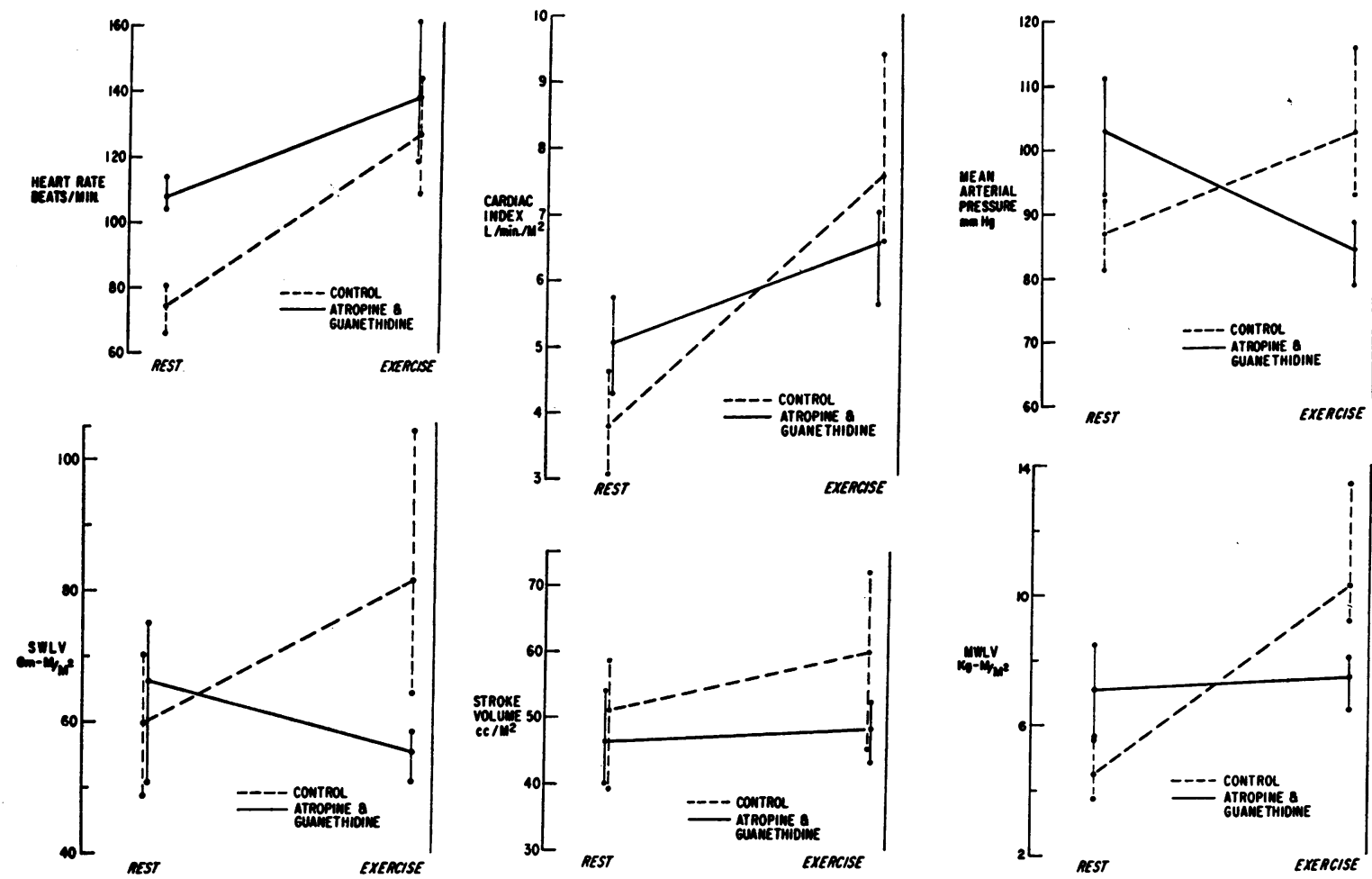

Fig. 1. A COMPARISON OF hEMOdYNAMIC MEASUREMENTS MAdE AT REST AND DURING EXERCISE DURING THE CONTROL STUdy (BROKEN LINES) AND AFTER ATROPINE AND GUANETHIDINE ADMINISTRATION (SOLID LINES). The range and mean values are shown for each measurement.

TABLE II

Measurements at rest and during exercise during the control period and after guanethidine*

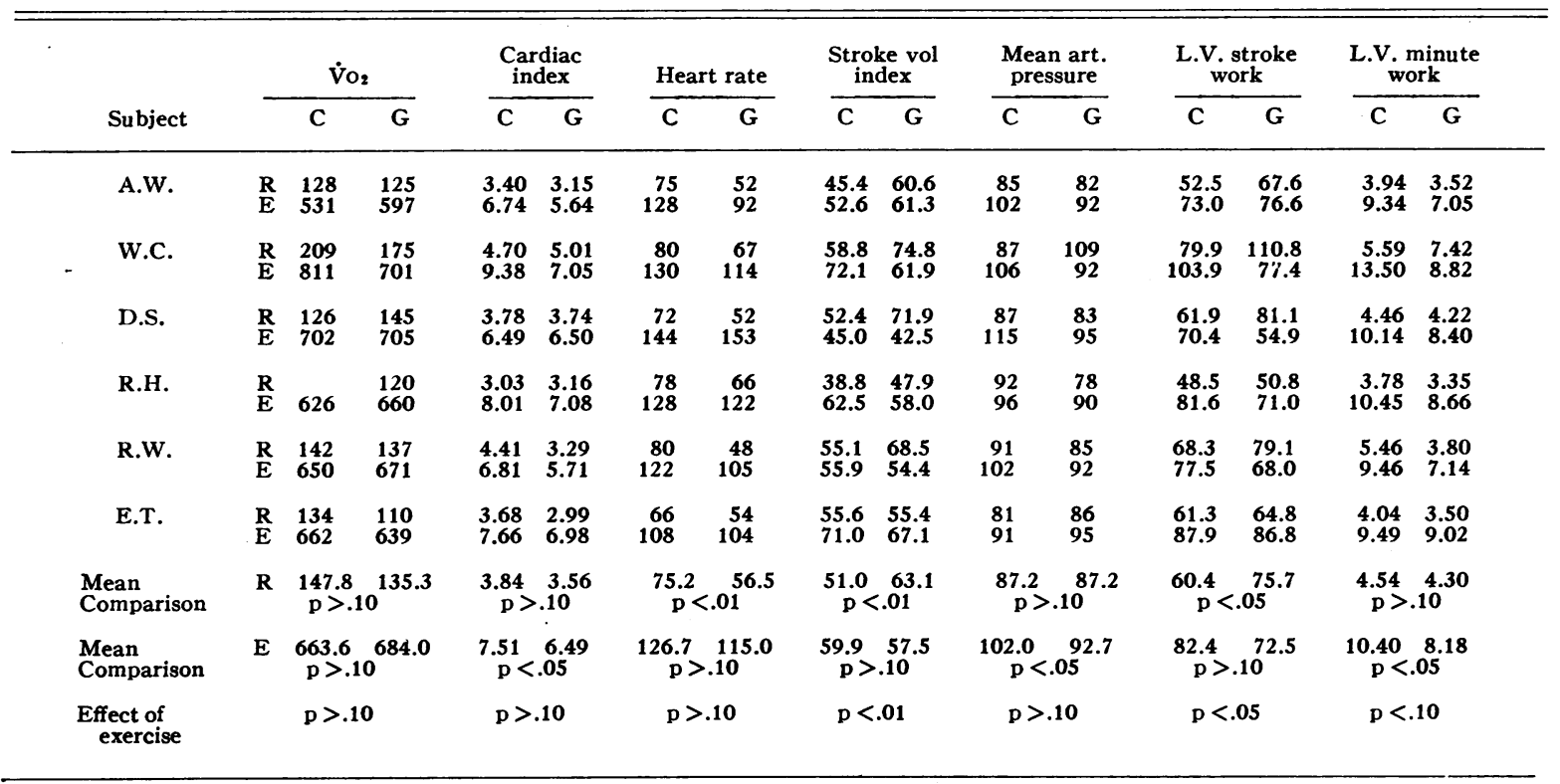

* $\mathrm{C}=$ control study (no drug); $\mathrm{G}=$ study after guanethidine; other abbreviations as in Table $\mathrm{I}$. 
TABLE III

Measurements at rest and during exercise during the control period and after guanethidine and atropine*

\begin{tabular}{|c|c|c|c|c|c|c|c|c|c|c|c|c|c|c|c|}
\hline \multirow[b]{2}{*}{ Subject } & \multicolumn{3}{|c|}{ V́o } & \multicolumn{2}{|c|}{$\begin{array}{c}\text { Cardiac } \\
\text { index }\end{array}$} & \multicolumn{2}{|c|}{ Heart rate } & \multicolumn{2}{|c|}{$\begin{array}{c}\begin{array}{c}\text { Stroke vol } \\
\text { index }\end{array} \\
\end{array}$} & \multicolumn{2}{|c|}{$\begin{array}{c}\text { Mean art. } \\
\text { pressure }\end{array}$} & \multicolumn{2}{|c|}{$\begin{array}{l}\text { L.V. stroke } \\
\text { work }\end{array}$} & \multicolumn{2}{|c|}{$\begin{array}{c}\text { L.V. minute } \\
\text { work }\end{array}$} \\
\hline & \multirow[b]{2}{*}{$\begin{array}{l}\mathrm{R} \\
\mathrm{E}\end{array}$} & \multirow{2}{*}{$\begin{array}{ll}\mathrm{C} \quad \mathrm{G} \\
128 \\
531\end{array}$} & \multirow{2}{*}{$\begin{array}{c}\mathrm{G} \text { and } \mathrm{A} \\
154 \\
613\end{array}$} & \multicolumn{2}{|c|}{$\widehat{C G \text { and } A}$} & \multirow{2}{*}{ 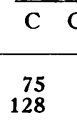 } & \multirow{2}{*}{$\begin{array}{c}\mathrm{G} \text { and } \mathrm{A} \\
107 \\
118\end{array}$} & \multicolumn{2}{|c|}{$\overline{\mathrm{CG} \text { and } \mathrm{A}}$} & \multirow{2}{*}{$\begin{array}{r}\mathrm{C} \\
85 \\
102\end{array}$} & \multirow{2}{*}{$\begin{array}{c}\mathrm{G} \text { and } \mathrm{A} \\
\begin{array}{c}111 \\
84\end{array}\end{array}$} & \multicolumn{2}{|c|}{$C \mathrm{G}$ and $\mathrm{A}$} & \multicolumn{2}{|c|}{$\mathrm{C}$ G and $\mathrm{A}$} \\
\hline A.W. & & & & $\begin{array}{l}3.40 \\
6.74\end{array}$ & $\begin{array}{l}5.54 \\
5.61\end{array}$ & & & $\begin{array}{l}45.4 \\
52.6\end{array}$ & $\begin{array}{l}51.8 \\
47.6\end{array}$ & & & $\begin{array}{l}52.5 \\
73.0\end{array}$ & $\begin{array}{l}78.1 \\
54.1\end{array}$ & $\begin{array}{l}3.94 \\
9.34\end{array}$ & $\begin{array}{l}8.36 \\
6.42\end{array}$ \\
\hline w.c. & $\underset{\mathbf{E}}{\mathbf{R}}$ & $\begin{array}{l}209 \\
811\end{array}$ & $\begin{array}{l}159 \\
698\end{array}$ & $\begin{array}{l}4.70 \\
9.38\end{array}$ & $\begin{array}{l}5.63 \\
7.00\end{array}$ & $\begin{array}{r}80 \\
130\end{array}$ & $\begin{array}{l}104 \\
143\end{array}$ & $\begin{array}{l}58.8 \\
72.1\end{array}$ & $\begin{array}{l}54.1 \\
49.0\end{array}$ & $\begin{array}{r}87 \\
106\end{array}$ & $\begin{array}{r}111 \\
84\end{array}$ & $\begin{array}{r}69.9 \\
103.9\end{array}$ & $\begin{array}{l}81.8 \\
56.0\end{array}$ & $\begin{array}{r}5.59 \\
13.50\end{array}$ & $\begin{array}{l}8.50 \\
8.01\end{array}$ \\
\hline D.S. & $\underset{\mathrm{E}}{\mathrm{R}}$ & $\begin{array}{l}126 \\
702\end{array}$ & $\begin{array}{l}157 \\
638\end{array}$ & $\begin{array}{l}3.78 \\
6.49\end{array}$ & $\begin{array}{l}4.48 \\
6.34\end{array}$ & $\begin{array}{r}72 \\
144\end{array}$ & $\begin{array}{l}110 \\
161\end{array}$ & $\begin{array}{l}52.4 \\
45.0\end{array}$ & $\begin{array}{l}40.6 \\
39.4\end{array}$ & $\begin{array}{r}87 \\
115\end{array}$ & $\begin{array}{l}92 \\
87\end{array}$ & $\begin{array}{l}61.9 \\
70.4\end{array}$ & $\begin{array}{l}50.9 \\
46.6\end{array}$ & $\begin{array}{r}4.46 \\
10.14\end{array}$ & $\begin{array}{l}5.60 \\
7.50\end{array}$ \\
\hline R.A. & $\underset{\mathrm{E}}{\mathrm{R}}$ & 626 & $\begin{array}{l}137 \\
659\end{array}$ & $\begin{array}{l}3.08 \\
8.01\end{array}$ & $\begin{array}{l}5.71 \\
7.01\end{array}$ & $\begin{array}{r}78 \\
128\end{array}$ & $\begin{array}{l}114 \\
134\end{array}$ & $\begin{array}{l}38.8 \\
62.5\end{array}$ & $\begin{array}{l}50.1 \\
52.4\end{array}$ & $\begin{array}{l}92 \\
96\end{array}$ & $\begin{array}{r}110 \\
78\end{array}$ & $\begin{array}{l}48.5 \\
81.6\end{array}$ & $\begin{array}{l}75.0 \\
55.5\end{array}$ & $\begin{array}{r}3.78 \\
10.45\end{array}$ & $\begin{array}{l}8.56 \\
7.44\end{array}$ \\
\hline R.W. & $\underset{\mathrm{R}}{\mathrm{R}}$ & $\begin{array}{l}142 \\
650\end{array}$ & $\begin{array}{l}139 \\
673\end{array}$ & $\begin{array}{l}4.41 \\
6.81\end{array}$ & $\begin{array}{l}4.24 \\
6.41\end{array}$ & $\begin{array}{r}80 \\
122\end{array}$ & $\begin{array}{l}106 \\
129\end{array}$ & $\begin{array}{l}55.1 \\
55.9\end{array}$ & $\begin{array}{l}40.0 \\
49.8\end{array}$ & $\begin{array}{r}91 \\
102\end{array}$ & $\begin{array}{l}95 \\
85\end{array}$ & $\begin{array}{l}68.3 \\
77.5\end{array}$ & $\begin{array}{l}51.6 \\
57.5\end{array}$ & $\begin{array}{l}5.46 \\
9.46\end{array}$ & $\begin{array}{l}5.47 \\
7.42\end{array}$ \\
\hline E.T. & $\underset{\mathrm{E}}{\mathrm{R}}$ & $\begin{array}{l}134 \\
662\end{array}$ & $\begin{array}{l}127 \\
615\end{array}$ & $\begin{array}{l}3.68 \\
7.66\end{array}$ & $\begin{array}{l}4.66 \\
6.93\end{array}$ & $\begin{array}{r}66 \\
108\end{array}$ & $\begin{array}{l}106 \\
142\end{array}$ & $\begin{array}{l}55.6 \\
71.0\end{array}$ & $\begin{array}{l}44.0 \\
48.8\end{array}$ & $\begin{array}{l}81 \\
91\end{array}$ & $\begin{array}{l}99 \\
88\end{array}$ & $\begin{array}{l}61.3 \\
87.9\end{array}$ & $\begin{array}{l}59.3 \\
58.4\end{array}$ & $\begin{array}{l}4.04 \\
9.49\end{array}$ & $\begin{array}{l}6.28 \\
8.29\end{array}$ \\
\hline $\begin{array}{l}\text { Mean } \\
\text { Comparison }\end{array}$ & $\mathbf{R}$ & $\begin{array}{c}147.8 \\
p>.\end{array}$ & $10^{145.5}$ & $\begin{array}{l}3.84 \\
\mathrm{p}<\text {. }\end{array}$ & $\begin{array}{l}5.04 \\
.10\end{array}$ & $\begin{array}{r}75.2 \\
\mathrm{p}<\end{array}$ & $<.01$ & $\stackrel{51.0}{\mathbf{p}>}$ & .16 .8 & $\stackrel{87.2}{\mathrm{p}<}$ & $<.01$ & $\begin{array}{r}60.4 \\
\mathrm{p}>\end{array}$ & .10 & $\begin{array}{c}4.54 \\
\text { p }<\text {. }\end{array}$ & 6.05 \\
\hline $\begin{array}{l}\text { Mean } \\
\text { Comparison }\end{array}$ & $\mathrm{E}$ & $\begin{array}{c}663.6 \\
\mathrm{p}>\text {. }\end{array}$ & $10^{649.3}$ & $\begin{array}{l}7.51 \\
\mathrm{p}<.\end{array}$ & .0 .55 & $\begin{array}{r}126.7 \\
p>\end{array}$ & $>.137 .8$ & $\stackrel{59.9}{\mathrm{p}}<$. & .01 .5 & $\begin{array}{r}102.0 \\
\mathrm{p}\end{array}$ & $<<.01$ & $\begin{array}{c}82.4 \\
p<.\end{array}$ & .05 & $\begin{array}{r}10.40 \\
\mathrm{p}<\end{array}$ & $.01^{7.51}$ \\
\hline $\begin{array}{c}\text { Effect of } \\
\text { exercise }\end{array}$ & & $\mathrm{p}>.1$ & & $\mathrm{p}<$. & .05 & & $<.01$ & $\mathrm{p}>$ & .10 & & $<.01$ & $\mathrm{p}<$ & & $\mathrm{p}<$. & .01 \\
\hline
\end{tabular}

* $\mathrm{C}=$ control study (no drug); $\mathrm{G}$ and $\mathrm{A}=$ study after guanethidine and atropine; other abbreviations as in Table I.

Changes from rest to exercise. The increases in mean values that occurred from the rest to the exercise state after atropine were significantly less than those during the control study for heart rate ( 33.5 compared to 51.5 beats per minute, $\mathrm{p}<.05$ ), left ventricular minute work (4.39 compared to $5.86 \mathrm{~kg}-\mathrm{m}$ per $\left.\mathrm{m}^{2}, \mathrm{p}<.05\right)$, and mean arterial pressure (6.5 compared to $14.8 \mathrm{~mm} \mathrm{Hg}, \mathrm{p}<.05$ ). No statistically significant differences were observed in any of the other measurements.

\section{Studies after guanethidine (Table II)}

Rest. Near the completion of the period of guanethidine administration, all of the subjects complained of fatigue and exhibited postural hypotension and "lightheadedness." The differences in systolic arterial pressure measured by cuff between the supine and erect positions ranged from 28 to $60 \mathrm{~mm} \mathrm{Hg}$ and averaged $39.7 \mathrm{~mm} \mathrm{Hg}$, whereas the differences in the diastolic pressures ranged from 10 to $28 \mathrm{~mm} \mathrm{Hg}$ and averaged 16.3 $\mathrm{mm} \mathrm{Hg}$. The mean resting heart rate during guanethidine administration (56.5 per minute) was significantly lower than during the control study $(75.2$ per minute, $\mathrm{p}<.01)$. There were no significant differences in the mean values for the cardiac index, mean arterial pressure, and left ventricular minute work. When compared to the mean values obtained at rest during the control state, the values measured during guanethidine administration were significantly greater for the stroke volume index (63.1 compared to $51.0 \mathrm{ml}$ per $\left.\mathrm{m}^{2}, \mathrm{p}<.01\right)$ and left ventricular stroke work index ( 75.7 compared to $60.4 \mathrm{~g}-\mathrm{m}$ per $\left.\mathrm{m}^{2}, \mathrm{p}<.05\right)$.

Exercise. When compared to values observed during exercise in the control study, the mean values were significantly lower for cardiac index (6.49 compared to $7.51 \mathrm{~L}$ per minute per $\mathrm{m}^{2}$, $\mathrm{p}<$ $.05)$, mean arterial pressure (92.7 compared to $102.0 \mathrm{~mm} \mathrm{Hg}, \mathrm{p}<.05$ ), and left ventricular minute work (8.18 compared to $10.40 \mathrm{~kg}-\mathrm{m}$ per $\mathrm{m}^{2}$, $\mathrm{p}<.05)$.

Changes from rest to exercise. During the control study, exercise resulted in an increase in the mean stroke volume index of $8.9 \mathrm{ml}$ per $\mathrm{m}^{2}$, whereas after guanethidine administration, exercise resulted in an average decline of the mean stroke volume index of $5.6 \mathrm{ml} \mathrm{per} \mathrm{m}^{2}$; these values were significantly different $(\mathrm{p}<.01)$. Whereas in the control study, exercise resulted in an increase in mean left ventricular stroke work of 22 $\mathrm{g}-\mathrm{m}$ per $\mathrm{m}^{2}$, after guanethidine the average value declined by $3.2 \mathrm{~g}-\mathrm{m}$ per $\mathrm{m}^{2}$ from rest to exercise $(p<.05)$. Exercise resulted in a smaller mean increase in left ventricular minute work after guanethidine administration $\left(3.88 \mathrm{~kg}-\mathrm{m}\right.$ per $\left.\mathrm{m}^{2}\right)$ than 
during the control period $\left(5.86 \mathrm{~kg}-\mathrm{m}\right.$ per $\left.\mathrm{m}^{2}\right)$, but these differences were not statistically significant $(\mathrm{p}<.10)$.

\section{Studies after atropine and guanethidine (Table III)}

Rest. When compared to the mean values obtained at rest in the control state, the combined administration of atropine and guanethidine resulted in significant elevations of heart rate $(107.8 \mathrm{com}$ pared to 75.2 beats per minute, $p<.01)$, left ventricular minute work ( 7.13 compared to $4.54 \mathrm{~kg}-\mathrm{m}$ per $\left.\mathrm{m}^{2}, \mathrm{p}<.05\right)$, and mean arterial pressure $(103.0$ compared to $87.2 \mathrm{~mm} \mathrm{Hg}, \mathrm{p}<.01$ ) (Figure 1). No significant changes in the other measurements were noted.

Exercise. When compared to the mean values observed during exercise in the control state, the mean values observed during exercise after both drugs were significantly less for the cardiac index (6.55 compared to $7.51 \mathrm{~L}$ per minute per $\mathrm{m}^{2}, \mathrm{p}<$ .05 ), stroke volume index (47.5 compared to 59.9 $\mathrm{ml}$ per $\left.\mathrm{m}^{2}, \mathrm{p}<.01\right)$, left ventricular stroke work ( 54.7 compared to $82.4 \mathrm{~g}-\mathrm{m}$ per $\mathrm{m}^{2}, \mathrm{p}<.05$ ), left ventricular minute work ( 7.51 compared to 10.40 kg-m per $\left.\mathrm{m}^{2}, \mathrm{p}<.01\right)$, and mean arterial pressure (84.3 compared to $102.0 \mathrm{~mm} \mathrm{Hg}, \mathrm{p}<.01$ ) (Figure 1).

Changes from rest to exercise. When compared to the increases occurring from rest to exercise in the control state, the changes that occurred after atropine and guanethidine were significantly less for the heart rate ( 30.0 compared to 51.5 beats per minute, $\mathrm{p}<.01)$, cardiac index $(1.51 \mathrm{com}$ pared to $3.67 \mathrm{~L}$ per minute per $\left.\mathrm{m}^{2}, \mathrm{p}<.05\right)$, left ventricular stroke work ( -11.4 compared to $+22.0 \mathrm{~g}-\mathrm{m}$ per $\left.\mathrm{m}^{2}, \mathrm{p}<.05\right)$, left ventricular minute work ( 0.38 compared to $5.86 \mathrm{~kg}-\mathrm{m}$ per $\mathrm{m}^{2}$, $\mathrm{p}<.01)$, and mean arterial pressure $(-18.7$ compared to $+14.8 \mathrm{~mm} \mathrm{Hg}, \mathrm{p}<.01$ ).

\section{DISCUSSION}

Ideally, assessment of the role played by the autonomic nervous system in the circulatory changes occurring during exercise would involve a comparison of the responses in normal individuals with responses after total autonomic denervation. Since this approach is obviously not applicable to man, pharmacologic inhibition of both components of the autonomic nervous system was utilized. In this study each subject served as his own control, and both the external work load and the oxygen consumption were essentially identical during exercise in all four studies.

The dose of atropine employed in this study is thought to produce total elimination of vagal inhibition (7). Guanethidine, a drug which selectively and effectively blocks the adrenergic nervous system (1) and produces myocardial catecholamine depletion (8), was utilized to produce sympathetic inhibition. The postural hypotension and marked fatigue experienced by the subjects were used as end-points to indicate the maximally tolerated doses. Further evidence of the effectiveness of the sympathetic blockade was the bradycardia which was present at rest. In addition, abolition of the post-valsalva hypertensive overshoot has been demonstrated in patients who were receiving comparable doses of guanethidine (9). Moreover, it has recently been shown that reflex venoconstriction is eliminated in patients who receive one-third of the dose of guanethidine used in the present study (10).

The elevation of heart rate and the decline in stroke volume and stroke work which atropine induced in the resting state were similar to those described by other workers (11). The only significant change produced by guanethidine in the supine resting state was a slowing of the heart rate; since cardiac index and minute work remained unchanged, stroke volume and stroke work actually rose significantly (Table II). These observations of the effect of guanethidine suggest that despite any decrease in myocardial contractility that may have occurred as a result of the administration of this drug (12), other factors, such as changes in ventricular end-diastolic volume, may have maintained cardiac output and thereby compensated for the sympathetic withdrawal. Had the resting measurements been carried out in the erect position, it is likely that the cardiac output and mean arterial pressure would have been lower during the period of guanethidine administration than during the control study.

At rest, the effects of atropine administration after the subjects had been receiving guanethidine were, in general, similar to those observed when atropine was given alone. The only notable difference was in the arterial pressure response; the 
mean arterial pressure rose an average of $3.8 \mathrm{~mm}$ $\mathrm{Hg}$ when atropine was administered to the untreated subjects and $15.8 \mathrm{~mm} \mathrm{Hg}$ after it was given to subjects on guanethidine. A possible explanation for this difference is that the atropineinduced elevation of cardiac output resulted in a reflex vasodilation in the untreated subjects, a phenomenon which was blocked by the prior administration of guanethidine.

Blockade of the parasympathetic nervous system alone did not interfere with the circulatory response to exercise. The heart rate, stroke volume, and mean arterial pressure rose in a manner so that the mean values of cardiac index and left ventricular minute work during exercise were almost identical in the untreated and atropinized subjects (Table I). In contrast to the effects of atropine, guanethidine produced a significant depression of the circulation during exercise. Mean values for cardiac index, arterial pressure, and left ventricular minute work during exercise were all significantly lower $(p<.05)$ when the subjects had been treated with this drug than when they were untreated. Although the stroke volume index rose during exercise from a mean value of 51.0 to $59.9 \mathrm{ml}$ per $\mathrm{m}^{2}$ in the untreated subjects, the mean value for the stroke volume index fell from 63.1 to $57.5 \mathrm{ml}$ per $\mathrm{m}^{2}$ after guanethidine, a significant difference $(\mathrm{p}<.01)$.

As noted above, the major changes produced by atropine were elevations of heart rate, cardiac index, and left ventricular minute work at rest, with less striking effects on these indices during exercise. In contrast, the predominant effect of guanethidine was to limit the values of these parameters reached during exercise while producing relatively little change in resting circulatory dynamics. As could be anticipated, a combination of these two effects was seen when both divisions of the autonomic nervous system were blocked by the combination of atropine and guanethidine. The subnormal circulatory response to exercise was reflected in significantly lower absolute values of cardiac index $(\mathrm{p}<.05)$, systemic arterial pressure $(\mathrm{p}<.01)$, and ventricular minute work $(\mathrm{p}<.01)$ during exercise after atropine and guanethidine than during the control study. In addition, the changes in these indices from rest to exercise followed a similar pattern. It should be stressed that the diminished cardiovascular response to ex- ercise was demonstrated in the supine position, and it is likely that an even more striking decrease in response would have occurred had the exercise been performed in the erect position.

The circulatory responses to exercise are attenuated by inhibition of the autonomic nervous system not only in intact, unanesthetized human subjects as shown in this study, but also in anesthetized, denervated dogs, as demonstrated by Chapman, Bruce, Baker, and Fisher (13). It should be noted, however, that in the present study the cardiac output response to exercise, although diminished, was not totally abolished by autonomic nervous inhibition. The mechanism responsible for the small increase in cardiac output produced by exercise after both drugs had been administered is not clear. It is possible that it is related to the decline in systemic arterial pressure which occurred during exercise, to the effects of circulating catecholamines, to the operation of Starling's law of the heart, or to incomplete pharmacologic inhibition of the autonomic nervous system. Although it is likely that the adrenergic nervous system was effectively inhibited by guanethidine with the dosage employed, the degree of completeness of the inhibition cannot be, assessed definitively. If the inhibition were only partial, however, an even greater decrease in the cardiovascular response to exercise would have occurred with complete blockade.

\section{SUMMARY}

In order to assess the contribution of the autonomic nervous system to the circulatory response to exercise, six normal subjects were studied at rest and during steady-state leg exercise in a control period without drugs and after pharmacologic inhibition of the autonomic nervous system. The latter was accomplished by the intravenous administration of atropine, $2 \mathrm{mg}$, and the oral administration of guanethidine for 21 to 26 days, with the maximal daily dosage ranging from 50 to $85 \mathrm{mg}$. During the control study, exercise resulting in a four- to fivefold increase in oxygen consumption produced average increases above resting values of 68 per cent in heart rate, 17 per cent in stroke volume index, 96 per cent in cardiac index, and 129 per cent in the left ventricular minute work. After combined administration of atropine and guanethidine, identical exercise re- 
sulted in average increases above resting values of 28 per cent in heart rate, 1 per cent in stroke volume, 30 per cent in cardiac index, and 5 per cent in left ventricular minute work. The absolute levels of stroke volume, cardiac output, and ventricular stroke work were significantly lower when the exercise was carried out after guanethidine and atropine than during the control study. Blockade of the parasympathetic nervous system alone elevated the heart rate, cardiac index, and left ventricular minute work at rest and did not interfere with the circulatory response to exercise. Guanethidine slowed the resting heart rate, but did not affect cardiac output or arterial pressure at rest. The cardiac index, mean arterial pressure, and left ventricular work during exercise were lower after guanethidine than during the control study. These studies demonstrate the important contribution made by the autonomic nervous system to the circulatory response to exercise in man and indicate that the sympathetic division plays the major role in this regard.

\section{ACKNOWLEDGMENTS}

The authors wish to express their appreciation to Miss Christine Miller and Mr. Jerome Cornfield for performance of the statistical analysis, and to Miss Helen Hood and Mr. Frederick Bullock for their assistance during the hemodynamic studies.

\section{REFERENCES}

1. Maxwell, R. A., Plummer, A. J., Schneider, F., Povalski, H., and Daniel, A. I. Pharmacology of [2-(octahydro-1-azocinyl)-ethyl]-guanidine sulfate (SU-5864). J. Pharmacol. exp. Ther. 1960, 128, 22.

2. Braunwald, E., and Kelly, E. R. The effects of exercise on central blood volume in man. $\mathrm{J}$. clin. Invest. 1960, 39, 413.
3. Shadle, O. W., Ferguson, T. B., Gregg, D. E., and Gilford, S. R. Evaluation of a new cuvette densitometer for determination of cardiac output. Circulat. Res. 1953, 1, 200.

4. Braunwald, E., Binion, J. T., Morgan, W. L., Jr., and Sarnoff, S. J. Alterations in central blood volume and cardiac output induced by positive pressure breathing and counteracted by Metaraminol (Aramine). Circulat. Res. 1957, 5, 670.

5. Chidsey, C. A., Frye, R. L., Kahler, R. L., and Braunwald, E. Influence of syrosingopine on the cardiovascular response to acute hypoxemia and exercise. Circulat. Res. 1961, 9, 989.

6. Scholander, P. F. Analyzer for accurate estimation of respiratory gases in one-half cubic centimeter samples. J. biol. Chem. 1947, 167, 235.

7. Craig, F. N. Effects of atropine, work, and heat on heart rate and sweat production in man. J. appl. Physiol. 1952, 4, 826.

8. Cass, R., Kuntzman, R., and Brodie, B. B. Norepinephrine depletion as a possible mechanism of action of guanethidine (SU 5864), a new hypotensive agent. Proc. Soc. exp. Biol. (N. Y.) 1960, $103,871$.

9. Kirkendall, W. M., Fitz, A. M., Van Hecke, D. C., Wilson, W. R., and Armstrong, M. L. Hemodynamic and clinical effects of guanethidine [Ismelin $\left.{ }^{\circledR}\right]$ in Summaries of reports presented at Symposium on Guanethidine (Ismelin ${ }^{\circledR}$ ), University of Tennessee College of Medicine, April 22, 1960, Ciba, pp. 33-35.

10. Braunwald, E., Mason, D. T., and Gaffney, T. E. Unpublished observations.

11. Berry, J. N., Thompson, H. K., Jr., Miller, D. E., and McIntosh, H. D. Changes in cardiac output, stroke volume, and central venous pressure induced by atropine in man. Amer. Heart J. 1959, 58, 204.

12. Gaffney, T. E., Braunwald, E., and Cooper, T. Analysis of the acute circulatory effects of guanethidine and bretylium. Circulat. Res. 1962, 10, 83.

13. Chapman, C. B., Bruce, T. A., Baker, O., and Fisher, J. N. The effect of partial and total denervation of the heart on left ventricular function (abstract). J. clin. Invest. 1960, 39, 976. 